\title{
Reproductive hormone secretion and testicular growth in bull calves actively immunized against testosterone and oestradiol-17及
}

\author{
M. J. D’Occhio*, D. R. Gifford†, R. M. Hoskinson $\ddagger$, T. Weatherly, \\ P. F. Flavel $\dagger$, P. E. Mattner $\ddagger$ and B. P. Setchell
}

Department of Animal Sciences, Waite Agricultural Research Institute, University of Adelaide, Glen Osmond, South Australia 5064; $†$ South Australian Department of Agriculture, Turretfield Research Centre, Rosedale, South Australia 5350; and $\ddagger$ CSIRO, Division of Animal Production, Prospect, New South Wales 2149, Australia

\begin{abstract}
Summary. Groups of bull calves received a primary immunization against testosterone (Group T; $\mathrm{N}=7$ ) or oestradiol-17 (Group E; $\mathrm{N}=9$ ) at 3 months of age and booster injections on four occasions at $\sim 2$ month intervals. Controls (Group $\mathrm{C}, \mathrm{N}=7$ ) were immunized against human serum albumin alone using the same protocol. Immunity was achieved against both steroids as judged by the secondary antisteroid antibody titres in Group T (730 \pm 231 ; reciprocal of titre) and Group E (12 205 \pm 4366$)$ bulls; however, peak antibody titres generally declined with successive booster injections. Mean plasma concentrations of LH, FSH and testosterone during the period from 3 to 10 months of age were higher $(P<0.05)$ in Group T bulls than in Groups $\mathrm{C}$ and $\mathrm{E}$. Group T bulls had larger testes compared with controls from 6 months of age onwards. At castration at 14 months of age, testes of Group T bulls were heavier $(P<0.05)$ than those of Groups $C$ and $E(179 \pm 13,145 \pm 8$ and $147 \pm 6 \mathrm{~g}$, respectively). At 10 months of age, there were no differences among treatment groups in $\mathrm{LH}$ responses to LHRH, but the testosterone responses were greater $(P<0.05)$ in bulls in Group T $(26.2 \pm 4.9 \mathrm{ng} / \mathrm{ml})$ and Group $\mathrm{E}(16.6 \pm 1.8 \mathrm{ng} / \mathrm{ml})$ compared with those in Group C $(6.9 \pm 0.6 \mathrm{ng} / \mathrm{ml})$. Testosterone responses to $\mathrm{hCG}$ determined at 13 months of age were also greater $(P<0.05)$ in Groups $\mathrm{T}$ and $\mathrm{E}$ relative to controls. At 14 months of age daily sperm production rates per bull $\left(\times 10^{-9}\right)$ were higher $(P<0 \cdot 10)$ in Group T bulls $(2 \cdot 2 \pm 0 \cdot 1)$ than those in Groups $C(1 \cdot 6 \pm 0 \cdot 2)$ and $E(1 \cdot 6 \pm 0 \cdot 1)$. These results indicate that early immunity against testosterone is associated with increased gonadotrophin secretion and accelerated growth of the testes in prepubertal bulls. Also, chronic immunity against testosterone or oestradiol-17 $\beta$ enhances the steroidogenic response of bull testes to gonadotrophic stimulation. If the above responses observed in young bulls are shown to be sustained, then immunity against gonadal steroids early in life may confer some reproductive advantage in mature animals.
\end{abstract}

\section{Introduction}

Growth and maturation of the testes in prepubertal bulls are acutely dependent on gonadotrophic stimulation (Schanbacher, 1981; Schanbacher et al., 1982). An increase in the frequency of pulsatile secretion of $\mathrm{LH}$ at around 3 months of age provides an endocrine signal which initiates testicular

\footnotetext{
*Present address: CSIRO, Division of Tropical Animal Science, Tropical Cattle Research Centre, Box 5545, Rockhampton Mail Centre, Queensland 4702, Australia.
} 
development in bull calves (Pelletier et al., 1981; Amann \& Walker, 1983; Schanbacher, 1984a). Coincident with testicular maturation there is elevated output of gonadal steroids which, in turn, imposes increasing feedback on LH secretion (Lacroix et al., 1977; Lacroix \& Pelletier, 1979). The serum LH profile in developing bull calves can therefore be described in general terms by low circulating concentrations during the first few months of life, a transient rise between 3 and 6 months of age, followed by relatively low concentrations until puberty (Pelletier et al., 1981). Based on the temporal relationships between LH secretion and testis development, approaches aimed at accelerating pubertal maturation in bulls might include (1) advancing the transient increase in pulsatile secretion of $\mathrm{LH}$ which appears to initiate maturation of the testes, (2) amplifying the transient rise in $\mathrm{LH}$, or (3) reducing the decline in $\mathrm{LH}$ associated with increased secretion of gonadal steroids. Follicle-stimulating hormone (FSH) is also considered important for testicular development (Courot et al., 1984); however, circulating concentrations of FSH appear to show little change during the prepubertal period in bulls (McCarthy et al., 1979; Amann \& Walker, 1983; D'Occhio et al., 1986).

Changes in the pattern of gonadotrophin secretion during various stages of development in prepubertal bulls are considered due, in part, to shifts in sensitivity of the hypothalamo-pituitary axis to gonadal steroid feedback (Amann \& Walker, 1983). Immunization against gonadal steroids which participate in feedback mechanisms modifies their actions at the hypothalamus and anterior pituitary gland and alters the hormonal interrelationships between the gonads and the brain (Haynes \& Southee, 1984; Scaramuzzi \& Hoskinson, 1984). In the present study, bull calves were immunized against testosterone and oestradiol-17 $\beta$ (oestradiol) in an attempt to influence, as a first step, the reproductive endocrinology of the prepubertal period.

\section{Materials and Methods}

Animals. Shorthorn bull calves were used in this study. Animals were maintained under field conditions and were weaned at 7 months of age. Body weights were determined at monthly intervals during the study. The diameter of each testis was also measured monthly using finely callibrated calipers.

Immunogens and immunization procedures. For immunization, testosterone-3-(O-carboxymethyl)oxime and oestradiol-6-(O-carboxymethyl)oxime were conjugated to human serum albumin using tetrahydrofuran in a mixed solvent procedure to activate the steroid with diimide reagent (Lindner et al., 1972). Proportions of reactants were: steroid acid (1 mM), ethyldimethylaminopropyl carbodiimide hydrochloride (1 $\mathrm{mM}$ ) and human serum albumin $(0.005 \mathrm{~mm}$ for testosterone-3-CMO; $0.01 \mathrm{~mm}$ for oestradiol-6-CMO). Conjugation occurred in phosphate buffer $(0.05 \mathrm{M}, \mathrm{pH} 7.8)$ over $16 \mathrm{~h}$ at ambient temperature. The tetrahydrofuran was evaporated from the reaction mixture under reduced pressure at $40^{\circ} \mathrm{C}$. The residue, comprising both soluble and insoluble products, was lyophilized and used as conjugate. Control bulls were immunized against human serum albumin alone. Steroid-protein conjugates were emulsified in Freund's complete adjuvant and administered subcutaneously along the brisket. Treatments included control (Group C, N = 7), testosterone-immunized (Group T, N =7) and oestradiol-immunized (Group E, $\mathrm{N}=9$ ) bull calves. Bull calves received a primary immunization at 3 months of age and booster immunizations on 4 occasions at $\sim 2$ month intervals thereafter. The same amounts of immunogen (equivalent to $5 \mathrm{mg}$ protein) and complete adjuvant were used for all immunizations.

Blood sampling and LHRH and hCG tests. Single blood samples were taken by jugular venepuncture weekly, but not always at the same time of day, to follow longitudinal changes in circulating concentrations of LH, FSH and testosterone. Pituitary and testicular responses after a bolus intravenous injection of native LHRH ( $5 \mathrm{ng} / \mathrm{kg}$ bodyweight; Sigma, St Louis, MO, U.S.A.) were ascertained at 10 months of age for 6 bulls selected at random from each treatment group. On this occasion bulls were equipped with an indwelling jugular vein cannula which was used both for blood sampling and LHRH injection. Relative to LHRH injection blood samples were taken at $-20,0,10,20,30$, 40, 60 and 120 min. Response of the testes to hCG (3000 i.u.; Sigma) was determined at 13 months of age for the same animals that had received LHRH. Bulls were similarly equipped with jugular vein cannulae and blood samples were taken $20 \mathrm{~min}$ before injection of hCG and at 20 -min intervals for $3 \mathrm{~h}$ after injection. Additional blood samples were taken by jugular venepuncture on Days 1, 2, 3, 4, 8 and 15 after hCG.

Testicular and epididymal weights and daily sperm production rates. At 14 months of age all bulls were castrated and testicular and epididymal weights recorded. Samples of testicular parenchyma were fixed in glutaraldehyde buffer (Forssmann et al., 1977) for determination of daily sperm production (DSP) rates using homogenization-haemocytometric techniques (see Amann, 1970). Samples (20-25 mg) of testicular parenchyma were minced for $3 \mathrm{~min}$ in $4 \mathrm{ml}$ homogenizing fluid (Johnson et al., 1981) using a Janke and Kunkel Ultra-Turrax fitted with a N8 probe. A time 
divisor of 5.32 days was used to calculate DSP from the number of spermatid nuclei in testicular homogenates (Amann et al., 1974).

Antibody titres and hormone assays. Circulating antibody titres were determined using procedures outlined in detail by Abraham (1974). Antibody titres for the respective steroid were taken as the plasma dilution which bound $50 \%$ of a constant mass of radiolabelled steroid $(\simeq 10 \mathrm{pg} ; \simeq 20000$ d.p.m.). Background binding, represented by the dilution of plasma from non-immunized bulls which bound $50 \%$ of radiolabelled steroid, was around $1: 10$ for both testosterone and oestradiol. Serum concentrations of LH and FSH were determined by double-antibody radioimmunoassays previously described (D'Occhio et al., 1986). An extraction single-antibody radioimmunoassay was used to measure plasma testosterone concentrations (D'Occhio \& Brooks, 1983). Vigorous extraction of samples into a toluene: hexane $(2: 1 \mathrm{v} / \mathrm{v})$ cocktail ensured that anti-testosterone antibody titres did not influence recoveries and that total testosterone was measured. Intra- and inter-assay coefficients of variation for all radioimmunoassays were $<10 \%$ based on duplicate samples. Sensitivities were $4 \mathrm{ng} \mathrm{FSH} / \mathrm{ml}, 0 \cdot 2 \mathrm{ng} \mathrm{LH} / \mathrm{ml}$ and $0 \cdot 1 \mathrm{ng}$ testosterone $/ \mathrm{ml}$.

Statistical analyses. Data were analysed by one-way or two-way analysis of variance procedures. Variables included treatment group, animals within treatment and, when appropriate, time. When necessary data were transformed to natural logarithms before analysis. If the analysis of variance showed significant effects then differences amongst treatment groups were assessed using the least significant difference test (Sokal \& Rohlf, 1969).

\section{Results}

\section{Antibody titres}

Antibody titres were relatively low in bulls in Groups $\mathrm{T}$ and $\mathrm{E}$ (Table 1), but were of the same order of magnitude as reported previously for cattle (Wise \& Schanbacher, 1983; Sreenan, 1984). Successive booster injections failed to induce titres that exceeded the initial secondary response. Also, booster injections induced a transient rise in antibody levels which was followed by a prompt decline in titres (see results for Weeks 8, 9 and 12 in Table 1).

Table 1. Antisteroid antibody titres (mean \pm s.e.m.) in bulls immunized against testosterone (Group $\mathrm{T} ; \mathrm{N}=7$ ) or oestradiol (Group $\mathrm{E}$,

$$
\mathrm{N}=9 \text { ) }
$$

\begin{tabular}{ccccc}
\hline \multirow{2}{*}{$\begin{array}{c}\text { Age } \\
\text { (months) }\end{array}$} & $\begin{array}{c}\text { Week of } \\
\text { treatment }\end{array}$ & $\begin{array}{c}\text { Vaccination } \\
\text { treatment }\end{array}$ & Group T & Group E \\
\cline { 3 - 5 } & 0 & Primary & 0 & 0 \\
\hline 3 & 8 & Boost 1 & $96 \pm 42$ & $1235 \pm 520$ \\
5 & 9 & & $730 \pm 231$ & $12205 \pm 4366$ \\
& 12 & & $396 \pm 124$ & $7690 \pm 2828$ \\
7 & 16 & Boost 2 & $243 \pm 101$ & $2017 \pm 547$ \\
& 17 & & $306 \pm 160$ & $2453 \pm 732$ \\
9 & 24 & Boost 3 & $65 \pm 26$ & $1065 \pm 329$ \\
& 25 & & $182 \pm 61$ & $1847 \pm 641$ \\
12 & 32 & Boost 4 & $55 \pm 36$ & $779 \pm 245$ \\
& 33 & & $216 \pm 117$ & $967 \pm 318$ \\
\hline
\end{tabular}

$\uparrow$ Titres are presented as reciprocal antisteroid antibody titres.

\section{Body weight}

There were no differences in body weights between treatment groups for the duration of the study (Fig. 1). There was a decrease in bodyweight gains associated with weaning at 7 months and the decline in body weights observed from 9 to 11 months of age for all groups resulted from poor quality summer pastures. 


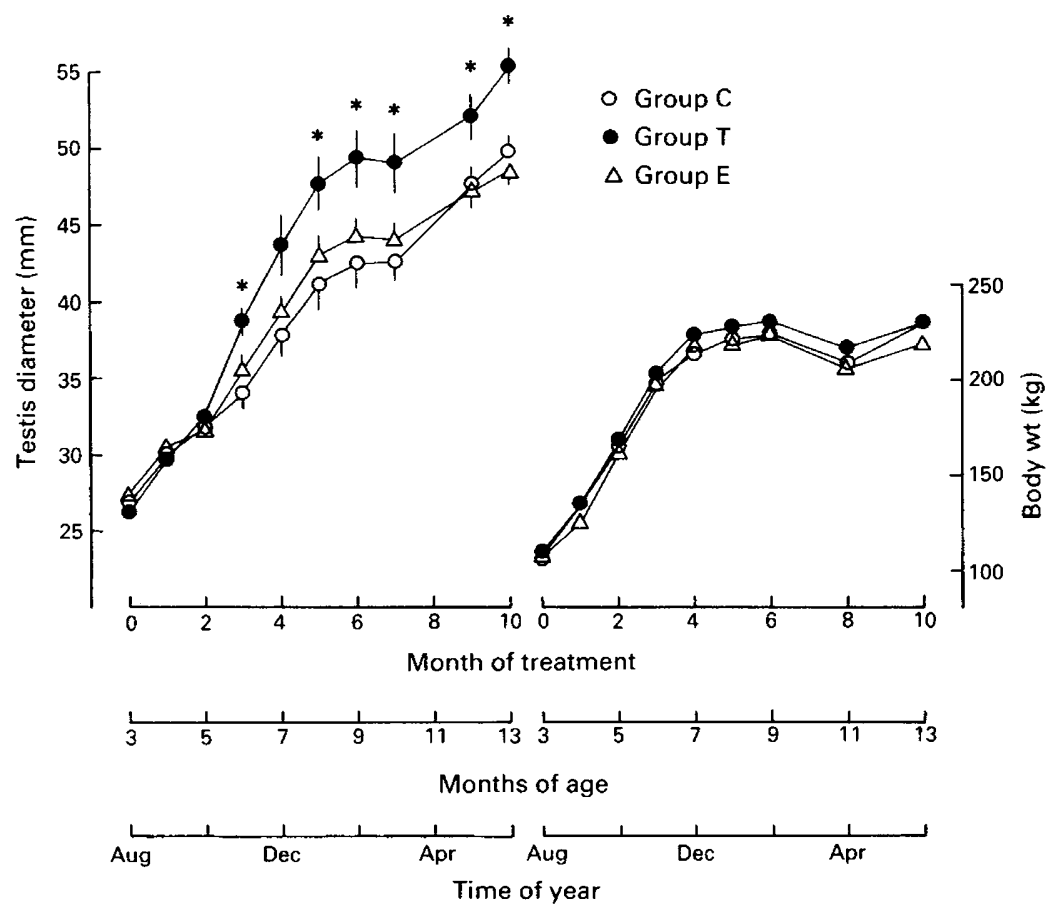

Fig. 1. Increases in bodyweights (means) and testicular diameter (mean \pm s.e.m.) in control bulls (Group C) and bulls actively immunized against testosterone (Group T) or oestradiol (Group E) from 3 months of age. For testicular diameter, when no s.e.m. is shown the variation was smaller than the size of the symbol. ${ }^{*} P<0.05$ compared with values for Group $C$ bulls.

Table 2. Plasma concentrations of LH, FSH and testosterone in control bulls (Group $\mathrm{C}$ ) and bulls actively immunized against testosterone (Group T) and oestradiol (Group E)

\begin{tabular}{lcccr}
\hline Group & $\begin{array}{c}\text { No. of } \\
\text { bulls }\end{array}$ & $\begin{array}{c}\text { LH } \\
(\mathrm{ng} / \mathrm{ml})\end{array}$ & $\begin{array}{c}\text { FSH } \\
(\mathrm{ng} / \mathrm{ml})\end{array}$ & \multicolumn{1}{c}{$\begin{array}{c}\text { Testosterone } \\
(\mathrm{ng} / \mathrm{ml})\end{array}$} \\
\hline $\mathrm{C}$ & 7 & $0.75 \pm 0.07^{\mathrm{a}}$ & $14 \cdot 7 \pm 0.3^{\mathrm{a}}$ & $3.9 \pm 0.3^{\mathrm{a}}$ \\
$\mathrm{T}$ & 7 & $1 \cdot 13 \pm 0.09^{\mathrm{b}}$ & $15.9 \pm 0.3^{\mathrm{b}}$ & $21.2 \pm 1 \cdot 3^{\mathrm{b}}$ \\
$\mathrm{E}$ & 8 & $0.88 \pm 0.07^{\mathrm{a}}$ & $14.5 \pm 0.3^{\mathrm{a}}$ & $6.6 \pm 0.5^{\mathrm{a}}$ \\
\hline
\end{tabular}

Values are mean \pm s.e.m. hormone concentrations during the period from 3 to 10 months of age.

Within columns, means without a common superscript differ ( $P<0.05 ;$ ANOVA, least significant difference test).

\section{LH, FSH and testosterone concentrations}

During the period from 3 to 10 months of age, bulls in Group T had higher $(P<0.05)$ mean plasma LH concentrations than did those in Groups C and E (Table 2). On a weekly basis, LH concentrations were consistently higher $(P<0.05)$ in Group T bulls only between 5 and 6 months of age. Plasma FSH did not differ amongst treatment groups at any single sampling time, but over the period from 3 to 10 months of age mean FSH concentrations were higher $(P<0.05)$ in Group $\mathrm{T}$ bulls than in those in Groups $\mathrm{C}$ and $\mathrm{E}$ (Table 2). Profiles of testosterone from 3 to 10 months of 
age are shown in Fig. 2. Testosterone concentrations in control bulls showed a gradual rise between 3 and 6 months of age and remained relatively constant thereafter. In Group $T$ bulls, testosterone increased sharply to reach maximum serum concentrations between 5 and 6 months of age, and then showed a progressive decline. A similar but significantly less pronounced trend was observed in Group E bulls. During the period from 3 to 10 months mean testosterone concentrations were higher $(P<0.001)$ in Group T bulls than in those in Groups $\mathrm{C}$ and $\mathrm{E}$ (Table 2).

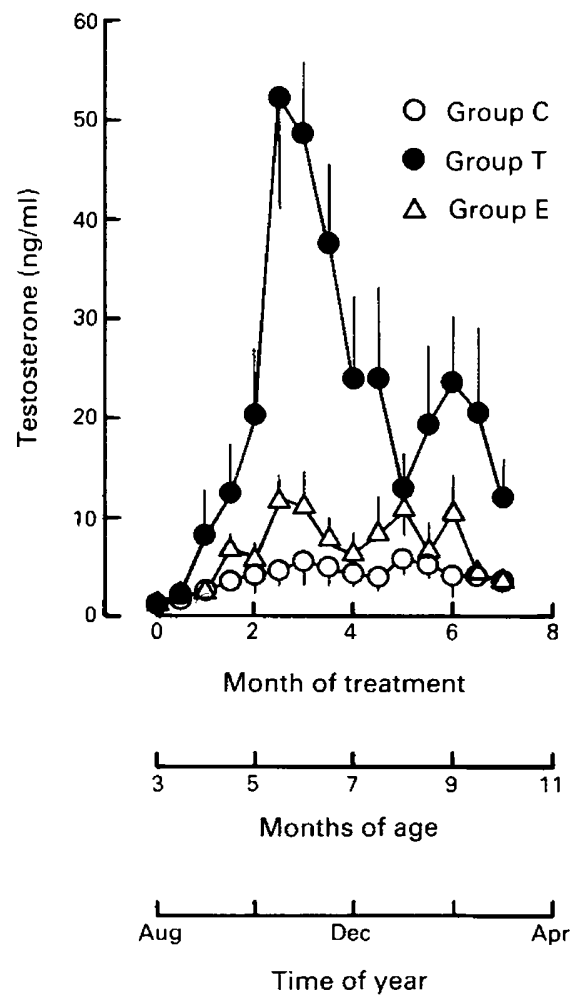

Fig. 2. Serum testosterone concentrations (mean \pm s.e.m.) in control bulls (Group C) and bulls actively immunized against testosterone (Group $T$ ) or oestradiol (Group E) from 3 months of age. When no s.e.m. is shown the variation was smaller than the size of the symbol.

Table 3. Measurements in 14-month-old control bulls (Group C), and bulls actively immunized against testosterone (Group T) or oestradiol (Group E)

\begin{tabular}{|c|c|c|c|c|c|c|c|}
\hline \multirow[b]{2}{*}{ Group } & \multirow[b]{2}{*}{$\begin{array}{l}\text { No. of } \\
\text { bulls }\end{array}$} & \multirow[b]{2}{*}{$\begin{array}{l}\text { Body wt } \\
(\mathrm{kg})\end{array}$} & \multirow[b]{2}{*}{$\begin{array}{l}\text { Testis diam. } \\
(\mathrm{mm})\end{array}$} & \multirow[b]{2}{*}{$\begin{array}{l}\text { Testis wt } \\
\text { (g) }\end{array}$} & \multirow[b]{2}{*}{$\begin{array}{l}\text { Epididymal } \\
\text { wt (g) }\end{array}$} & \multicolumn{2}{|c|}{ Daily sperm production } \\
\hline & & & & & & $\begin{array}{c}\text { Per gram testis } \\
\text { parenchyma }\left(\times 10^{-6}\right)\end{array}$ & $\begin{array}{l}\text { Per bull } \dagger \\
\left(\times 10^{-9}\right)\end{array}$ \\
\hline $\mathrm{C}$ & 7 & $229 \pm 4^{a}$ & $49 \pm 1^{\mathrm{a}}$ & $145 \pm 8^{a}$ & $12 \cdot 0 \pm 0 \cdot 5^{\mathrm{a}}$ & $6.3 \pm 0.9^{a}$ & $1.6 \pm 0.2^{c}$ \\
\hline $\mathrm{T}$ & 7 & $230 \pm 4^{\mathrm{a}}$ & $55 \pm 1^{b}$ & $179 \pm 13^{b}$ & $12 \cdot 2 \pm 1 \cdot 1^{\mathrm{a}}$ & $6.9 \pm 0.4$ & $2 \cdot 2 \pm 0.1^{\circ}$ \\
\hline E & 8 & $219 \pm 8^{a}$ & $48 \pm 1^{2}$ & $147 \pm 6^{a}$ & $10 \cdot 5 \pm 0.5^{a}$ & $6.4 \pm 0.4^{a}$ & $1.6 \pm 0.1^{\circ}$ \\
\hline
\end{tabular}

Values are means \pm s.e.m.

Within columns, means without a common superscript differ $\left({ }^{a, b} P<0 \cdot 05 ;{ }^{c, d} P<0 \cdot 10\right.$; ANOVA, least significant difference test).

$†$ Tunica albuginea was assumed to constitute $10 \%$ of weight of the testis (see Amann \& Almquist, 1962). 
Testicular size, testicular and epididymal weights, and daily sperm production rates

From 6 months of age onwards, Group T bulls had larger $(P<0.05)$ testes than did Group C bulls (Fig. 1). Testicular diameter in Group $\mathrm{E}$ bulls was intermediate between that of bulls in Groups $T$ and $C$ from 6 to 10 months. At castration at 14 months, testes of Group $T$ bulls were heavier $(P<0.05)$ than those of bulls in Groups $\mathrm{C}$ and $\mathrm{E}$ which did not differ from one another (Table 3). Epididymal weights did not differ amongst treatment groups (Table 3). There were also no differences amongst treatment groups in DSP rates per unit weight of testicular parenchyma. However, when DSP was calculated for both testes, bulls in Group T had a higher $(P<0 \cdot 10)$ DSP rate compared with those in Groups $\mathrm{C}$ and $\mathrm{E}$ (Table 3 ). Daily sperm production rates across all treatments were generally low for 14-month-old bulls; however, this was associated with low body weights and it can be concluded that both DSP and bodyweight were adversely influenced by the poor pasture conditions which prevailed during summer.

\section{Responses to $L H R H$ and $h C G$}

LH and testosterone concentrations after administration of LHRH are presented in Table 4. There were no differences amongst treatment groups in LH responses to LHRH although the $\Delta \mathrm{LH}$ values tended to be greater in Group $\mathrm{E}$ animals. Increases in testosterone in the $2 \mathrm{~h}$ after LHRH were lower $(P<0.05)$ in Group $\mathrm{C}$ than in Group $\mathrm{T}$ and Group $\mathrm{E}$ bulls which did not differ from

Table 4. LH and testosterone responses after bolus intravenous injections of LHRH ( $5 \mathrm{ng} / \mathrm{kg}$ bodyweight), at 10 months of age and hCG (3000 i.u.) at 13 months of age, in control bulls (Group C) and bulls actively immunized against testosterone (Group $\mathrm{T}$ ) or oestradiol (Group E)

\begin{tabular}{|c|c|c|c|c|c|}
\hline \multirow[b]{3}{*}{ Group } & \multirow{3}{*}{$\begin{array}{l}\text { No. of } \\
\text { bulls }\end{array}$} & \multicolumn{2}{|c|}{ LHRH } & \multirow{2}{*}{\multicolumn{2}{|c|}{$\frac{\mathrm{hCG}}{\text { Testosterone }}$}} \\
\hline & & \multirow{2}{*}{$\begin{array}{c}\text { LH } \\
(0-20 \mathrm{~min})\end{array}$} & \multirow{2}{*}{$\begin{array}{l}\text { Testosterone } \\
(0-2 \mathrm{~h})\end{array}$} & & \\
\hline & & & & $0-3 \mathrm{~h}$ & Day 4 \\
\hline $\mathrm{C}$ & 6 & $4 \cdot 1 \pm 0 \cdot 3^{a}$ & $6.9 \pm 0.6^{a}$ & $8 \cdot 4 \pm 1 \cdot 5^{a}$ & $13 \cdot 4 \pm 2 \cdot 8^{\mathrm{a}}$ \\
\hline $\mathrm{T}$ & 6 & $3.7 \pm 0.4^{2}$ & $26 \cdot 2 \pm 4.9^{b}$ & $31.9 \pm 6.7^{b}$ & $37 \cdot 0 \pm 4 \cdot 1^{\mathrm{b}}$ \\
\hline E & 6 & $5 \cdot 3 \pm 0.9^{a}$ & $16.6 \pm 1.8^{b}$ & $20 \cdot 5 \pm 2 \cdot 7^{\mathrm{b}}$ & $20.5 \pm 1.9^{a}$ \\
\hline
\end{tabular}

Values represent peak hormone concentrations during the respective times after injection of LHRH or hCG and are presented as means \pm s.e.m.

Within columns, means without a common superscript differ $(P<0.05$; ANOVA, least significant difference test).

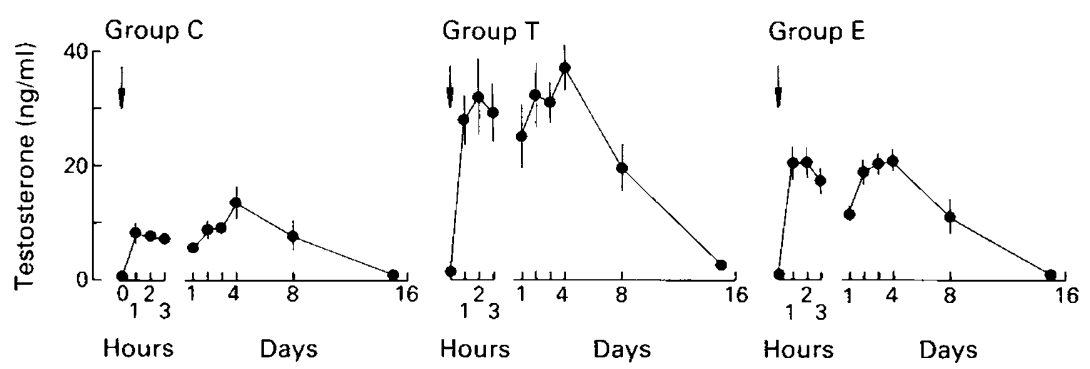

Fig. 3. Testosterone responses to a bolus intravenous injection of hCG ( 3000 i.u. arrow) in control bulls (Group C) and bulls immunized from 3 months of age against testosterone (Group T) or oestradiol (Group E). Values are mean \pm s.e.m. for 6 bulls; when no s.e.m. is shown the variation was smaller than the size of the symbol. 
one another. Increases in circulating concentrations of testosterone after intravenous injection of hCG are depicted in Fig. 3 and the results are summarized in Table 4. Acute testosterone responses to hCG $(0$ to $3 \mathrm{~h})$ were lower $(P<0.05)$ in Group $\mathrm{C}$ bulls than in those in Groups $\mathrm{T}$ and $\mathrm{E}$ which did not differ from one another. For all treatment groups, testosterone concentrations continued to increase between Days 1 and 4 after administration of hCG, suggesting that maximal secondary responses may have occurred between Days 4 and 8 . By Day 8 testosterone concentrations had begun to decline. Nevertheless, by 4 days after hCG injection testosterone concentrations in Group $\mathrm{T}$ bulls were higher $(P<0.05)$ than in those in Groups $\mathrm{C}$ and $\mathrm{E}$ which did not differ from one another.

\section{Discussion}

The present study sought to determine whether active immunization against gonadal steroids early in life may provide an approach for influencing the reproductive endocrinology of the prepubertal period in the bull. It was found that bull calves actively immunized against testosterone had higher circulating concentrations of LH, FSH and testosterone during the prepubertal period and these animals also showed increased rates of testicular growth. We suggest that immunization against testosterone reduced feedback on the hypothalamo-pituitary axis resulting in increased gonadotrophic stimulation of the testes (Nieschlag \& Wickings, 1978). Differences in LH concentrations between testosterone-immunized and control bulls were most apparent between 5 and 6 months and less evident thereafter. Similar transient changes in LH concentrations in the face of sustained high antibody titres have previously been demonstrated in rabbits (Thorneycroft et al., 1975) and monkeys (Wickings \& Nieschlag, 1978) immunized against testosterone. It is possible that, with continued testosterone immunity, circulating concentrations of metabolites of testosterone such as $5 \alpha$-dihydrotestosterone and oestradiol might increase, and these metabolites may in turn assume increased importance in feedback on LH (Wickings \& Nieschlag, 1978). Both $5 \alpha$-dihydrotestosterone and oestradiol suppress gonadotrophin secretion in the bull (Gettys et al., 1984). The results of the present study agree with other findings for monkeys (Wickings \& Nieschlag, 1978), rams (Schanbacher, 1982), rabbits (Thorneycroft et al., 1975), and rats (Hillier et al., 1975), but contrast with the results of Walker et al. (1984) who observed no increases in gonadotrophin secretion in prepubertal bulls immunized against testosterone. An unexpected decrease in plasma concentrations of LH and FSH was observed in prepubertal boars actively immunized against testosterone (Thompson et al., 1985). The lack of effect of oestradiol immunization on LH concentrations observed in the present study was consistent with results of oestradiol immunization in the rat (Hillier et al., 1975) and oestrone immunization in the stallion (Thompson \& Honey, 1984). The latter findings do not necessarily exclude a role for oestrogens in control of gonadotrophins in the male since feedback would presumably be maintained in oestrogen-immunized individuals by normal or slightly elevated testosterone concentrations. However, Schanbacher (1984b) reported increased circulating concentrations of both $\mathrm{LH}$ and testosterone in rams actively immunized against oestradiol.

The initial sharp rise in plasma testosterone concentrations between 5 and 6 months in bulls immunized against testosterone, followed by a gradual decline, also was of interest. Such a testosterone pattern may have been related to a general decline in peak antibody response to booster immunization. Testosterone concentrations are a function of secretion and clearance rates, the latter being influenced by testosterone binding capacity in plasma (Wickings et al., 1976). A direct relationship between circulating antibody titres and testosterone might therefore be anticipated. Similar longitudinal changes in circulating testosterone in response to testosterone immunization have also been observed in developing rams (Haynes \& Southee, 1984).

Increased rates of testicular growth in testosterone-immunized prepubertal animals similar to those observed in the present study have been reported for bulls (Walker et al., 1984) and rams (Haynes \& Southee, 1984) but were not observed for boars (Thompson et al., 1985). In prepubertal 
stallions, increased testicular growth was induced by active immunization against oestrone (Thompson \& Honey, 1984) whilst passive immunization against oestrone and oestradiol produced the same responses in young rams (Land et al., 1981). From studies of adult rats (Hillier et al., 1975) and rabbits (Nieschlag et al., 1975) it would appear that increased testicular size in testosteroneimmunized animals involves both hyperplasia and hypertrophy of the interstitial tissue.

The testes of bulls immunized against testosterone secreted larger amounts of testosterone than did those of controls in response to administration of both LHRH and hCG. This was no doubt due, in part, to the larger testicular size of these animals and possible proliferation of the Leydig cells. However, it is also likely that testes of such bulls had an increased sensitivity to gonadotrophin as has been demonstrated for immunized rabbits (Nieschlag et al., 1975). It could also be argued that increased testosterone concentrations in testosterone-immunized bulls after LHRH and hCG injection were due to greater plasma binding capacity and decreased testosterone clearance rate in these animals (see Thompson et al., 1985). However, the initial sharp rise in plasma testosterone in such bulls in response to gonadotrophic stimulation argues for an increased capacity for testosterone secretion. Bulls immunized against oestradiol also secreted more testosterone compared with controls in response to LHRH and hCG. Testicular size of oestradiolimmunized bulls was similar to that of controls, suggesting different mechanisms for increased sensitivity to gonadotrophin between bulls immunized against oestradiol and testosterone. Oestrogens have been proposed as having a direct negative influence on steroid biosynthesis in the testes of some species (see D'Occhio et al., 1984). Immunity against oestradiol may therefore alter possible direct actions of this steroid within the bovine testis, allowing increased steroidogenic responses to gonadotrophin input. Unstimulated testosterone concentrations were elevated in oestradiol-immunized rats (Hillier et al., 1975) and rams (Schanbacher, 1984b) and oestroneimmunized young stallions (Thompson \& Honey, 1984), and a slight increase in circulating testosterone was observed in the bulls immunized against oestradiol in the present study.

In summary, the present study has demonstrated that active immunity against testosterone early in life increases gonadotrophin secretion in the bull and accelerates growth of the testes. Whether this approach can be used to enhance overall reproduction performance of mature bulls remains to be determined. However, encouraging observations were that total daily sperm production rates are increased in young testosterone-immunized bulls and there are no effects of this treatment on the weight of the epididymis, an androgen-dependent organ important for sperm maturation and storage. The latter observation was consistent with normal seminal characteristics reported for young testosterone-immunized bulls (Walker et al., 1984). Since immunity against gonadal steroids appears not to diminish sexual behaviour in the male (Haynes \& Southee, 1984), it is possible that immunity against testosterone early in life may confer some lifetime reproductive advantages in the bull.

We thank Dr D. J. Bolt (USDA, Baltimore, Maryland, U.S.A.), Dr R. I. Cox (CSIRO, Division of Animal Production, Prospect, Australia), Dr J. J. Reeves (Washington State University, Washington, U.S.A.), and the NIADDK for generous supplies of radioimmunoassay materials; Mr M. Bald, Mr R. Rowsell, Mr J. Zupp, Mr B. E. Harrison and Mr R. J. Welch for expert technical assistance; Miss M. Morris for advice on statistical analyses; Mrs S. Suter for typing the manuscript; Mr B. Milligan and Mr R. Norton for management of the animals; and Emeritus Professor W. P. Rogers for making available facilities at "Lirra Lirra" and for his continued cooperation. The study was supported in part by a grant from the J. S. Davies Bequest.

\section{References}

Abraham, G.E. (1974) Radioimmunoassay of steroids in biological materials. Acta endocr., Copenh. 75 (Suppl. 183), $7-42$

Amann, R.P. (1970) Sperm production rates. In The
Testis, Vol. 1, Development, Anatomy and Physiology, pp. 433-482. Eds A. D. Johnson, W. R. Gomes \& N. L. VanDemark. Academic Press, New York.

Amann, R.P. \& Almquist, J.O. (1962) Reproductive 
capacity of dairy bulls. VIII. Direct and indirect measurement of testicular sperm production. J. Dairy Sci. 45, 774-781.

Amann, R.P. \& Walker, O.A. (1983) Changes in the pituitary-gonadal axis associated with puberty in Holstein bulls. J. Anim. Sci. 57, 433-442.

Amann, R.P., Kavanaugh, J.F., Griel, L.C. \& Voglmayr, J.K. (1974) Sperm production of Holstein bulls determined from testicular spermatid reserves, after cannulation of rete testis or vas deferens, and by daily ejaculation. J. Dairy Sci. 57, 93-99.

Courot, M., Pisselet, C., Kilgour, R.J., Sairam, M.R. \& Dubois, M.P. (1984) Developpement testiculaire, nombre de cellules de Sertoli et spermatogenese chez des agneaux immunises passivement contre $\beta$ FSH ovine. In Développements récents de l'Endocrinologie du Testicule (Coll. INSERM No. 123), pp. 163-168. Eds J. M. Saez, M. G. Forest, A. Dazard \& J. Bertrand. Inserm, Paris.

D’Occhio, M.J. \& Brooks, D.E. (1983) Seasonal changes in plasma testosterone concentration and mating activity in Border Leicester, Poll Dorset, Romney and Suffolk rams. Aust. J. exp. Agric. Anim. Husb. 23, 248-253.

D'Occhio, M.J., Schanbacher, B.D. \& Kinder, J.E. (1984) In vitro testosterone secretion by testicular tissue from young bulls and the effects of chronic and acute exposure to estradiol-17ß. J. Anim. Sci. 58, 949-954.

D'Occhio, M.J., Gifford, D.R., Weatherly, T. \& Setchell, B.P. (1986) Evidence of gonadal steroid-independent changes in activity of the central LH-releasing hormone pulse generator in developing bull calves. $J$. Endocr. 111, 67-73.

Forssmann, W.G., Ito, S., Weihe, E., Aokj, A., Dym, M. \& Fawcett, D.W. (1977) An improved perfusion fixation method for the testis. Anat. Rec. 188, 307-314.

Gettys, T.W., D’Occhio, M.J., Henricks, D.M. \& Schanbacher, B.D. (1984) Suppression of LH secretion by oestradiol, dihydrotestosterone and trenbolone acetate in the acutely castrated bull. $J$. Endocr. $100,107-112$.

Haynes, N.B. \& Southee, J.A. (1984) Effects of immunization against steroid hormones on male endocrinology. In Immunological Aspects of Reproduction in Mammals, pp. 427-444. Ed. D. B. Crighton. Butterworths, London.

Hillier, S.G., Groom, G.V., Boyns, A.R. \& Cameron, E.H.D. (1975) Effects of active immunization against steroids upon circulating hormone concentrations. $J$. Steroid Biochem. 6, 529-535.

Johnson, L., Petty, C.S. \& Neaves, W.B. (1981) A new approach to quantification of spermatogenesis and its application to germinal cell attrition during human spermiogenesis. Biol. Reprod. 25, 217-226.

Lacroix, A. \& Pelletier, J. (1979) Short-term variations in plasma LH and testosterone in bull calves from birth to 1 year of age. J. Reprod. Fert. 55, 81-85.

Lacroix, A., Garnier, D-H. \& Pelletier, J. (1977) Temporal fluctuations of plasma $\mathrm{LH}$ and testosterone in Charolais bull calves during the first year of life. Annls Biol. anim. Biochim. Biophys. 17, 1013-1019.

Land, R.B., Baird, D.T. \& Carr, W.R. (1981) Increased testicular growth of Tasmanian Merino ram lambs treated with antisera to oestrogens. J. Reprod. Fert. 62, 151-158.

Lindner, H.R., Perel, E., Friedlander, A. \& Zeitlin, A. (1972) Specificity of antibodies to ovarian hormones in relation to the site of attachment of the steroid haptens to the peptide carrier. Steroids 19, 357-375.

McCarthy, M.S., Hafs, H.D. \& Convey, E.M. (1979) Serum hormone patterns associated with growth and sexual development in bulls. J. Anim. Sci. 49, 1012-1020.

Nieschlag, E. \& Wickings, E.J. (1978) Biological effects of antibodies to gonadal steroids. Vitams Horm. 36, 165-202.

Nieschlag, E., Usadel, K.H. \& Kley, H.K. (1975) Active immunization with steroids as an approach to investigating testicular and adrenal feedback control. $J$. Steroid Biochem. 6, 537-540.

Pelletier, J., Carrez-Camous, S. \& Thiery, J.C. (1981). Basic neuroendocrine events before puberty in cattle, sheep and pigs. J. Reprod. Fert., Suppl. 30, 91-102.

Scaramuzzi, R.J. \& Hoskinson, R.M. (1984) Active immunization against steroid hormones for increased fecundity. In Immunological Aspects of Reproduction in Mammals, pp. 445-474. Ed. D. B. Crighton. Butterworths, London.

Schanbacher, B.D. (1981) Importance of the episodic nature of luteinizing hormone secretion for normal development of the bovine testis during puberty: interference with oestradiol-17ß. $J$. Endocr. 88, 393-400.

Schanbacher, B.D. (1982) Responses of ram lambs to active immunization against testosterone and luteinizing hormone-releasing hormone. Am. J. Physiol. 242, E201-E205.

Schanbacher, B.D. (1984a) Pituitary-testicular responses of estradiol-17 $\beta$-implanted bull calves to continuous versus pulsatile infusion of luteinizing hormone releasing hormone. J. Anim. Sci. 58, 943-948.

Schanbacher, B.D. (1984b) Regulation of luteinizing hormone secretion in male sheep by endogenous estrogen. Endocrinology 115, 944950.

Schanbacher, B.D., D'Occhio, M.J. \& Kinder, J.E. (1982) Initiation of spermatogenesis and testicular growth in oestradiol-17ß-implanted bull calves with pulsatile infusion of luteinizing hormone releasing hormone. J. Endocr. 93, 183-192.

Sokal, R.R. \& Rohlf, F.J. (1969) In Biometry, pp. 235-252. W. H. Freeman and Company, San Francisco.

Sreenan, J.M. (1984) Steroid immunization in cows: potential for increasing ovulation and twinning rates. Proc. 10th Int. Cong. Anim. Reprod. \& A.I., UrbanaChampaign, Vol. IV, pp. VIII-22-VIII-27.

Thompson, D.L. \& Honey, P.G. (1984) Active immunization of prepubertal colts against estrogens: hormonal and testicular responses after puberty. J. Anim. Sci. 59, 189-196.

Thompson, D.L., Southern, L.L., St George, R.L., Jones, L.S. \& Garza, F. (1985) Active immunization of prepubertal boars against testosterone: testicular and endocrine responses at 14 months of age. J. Anim. Sci. 61, 1498-1504.

Thorneycroft, I.H., Thorneycroft, N.K., Scaramuzzi, R.J. \& Blake, C.A. (1975) Radioimmunoassay of serum 
LH and testosterone in male rabbits actively immunized against testosterone. Endocrinology 97, 301-306.

Walker, M.P., Thompson, D.L., Godke, R.A. \& Honey, P.G. (1984) Active immunization of prepubertal bulls against testosterone: seminal and testicular characteristics after puberty. Theriogenology 22, 269-278.

Wickings, E.J. \& Nieschlag, E. (1978) The effects of active immunization with testosterone on pituitarygonadal feedback in the male Rhesus monkey (Macaca mulatta). Biol. Reprod. 18, 602-607.
Wickings, E.J., Becher, A. \& Nieschlag, E. (1976) Testosterone metabolism in rabbits actively immunized with testosterone. Endocrinology 98, 1142-1146.

Wise, T.H. \& Schanbacher, B.D. (1983) Reproductive effects of immunizing heifers against androstenedione and oestradiol-17ß. J. Reprod. Fert. 69, $605-612$.

Received 12 February 1986 